\title{
MEASURING EXPERIENCE IN INTERNATIONAL BUSINESS: A SYSTEMATIC LITERATURE REVIEW
}

\author{
João PARRACHO \\ Católica Porto Business School Universidade Católica Portuguesa, Portugal \\ Susana SILVA* \\ Católica Porto Business School Universidade Católica Portuguesa, Portugal
}

\begin{abstract}
The paper explores the indicators that measure the experience in international business. Literature review was used to ascertain the state of the art of the existing indexes and theories. The internationalisation of businesses is a fundamental strategic step to increase companies' competitive advantage and profits. Nevertheless, even though internationalisation is widely accepted as an important source of value for companies and is a broad object of investigation, there is still much to study about how to measure experience at the level of international business. The absence of a coherent approach to measure experience in international businesses in past empirical studies made it difficult to create a solution with theoretical concepts that would support further studies in this matter. The results are not contradictory, but complementary, as, through individual internationalization indicators, it is possible to evolve and create indices, such as the Transnationality Index or the Transnational Activities Spread Index. The biggest constraint on the analysed indices is the fact that they focus mainly on the internationalisation of transnational companies and the type of data that was used to build the indexes (secondary data). However, by studying international experience through the number of years and the network spread, it is possible to overcome some of the existing challenges.
\end{abstract}

Keywords: international experience, internationalisation experience, business experience, international business experience;

JEL classification: M16; F23; F20.

\footnotetext{
* Corresponding author. Address: Católico Porto Business School, Universidade Católica Portuguesa Rua Diogo Botelho, 1327 4169-005 Porto, Portugal., Tel: +351 226196000 , E-mail: ssilva@porto.ucp.pt
} 


\section{Introduction}

International experience is an important and intangible asset that can facilitate the internationalisation process and alleviate risks and problems related to the liability of foreignness (Barkema, Bell, \& Pennings, 1996 in Batsakis \& Singh, 2019). Firms with higher levels of international business experience are better prepared to mitigate potential problems during the internationalisation process, cope with complex differences in the new market, and end up managing associated costs of doing business in an international environment more effectively (Batsakis \& Singh, 2019). Even though internationalisation is widely accepted as an important source of value for companies and it is a wide subject of research, there is still much to be studied about international experience and how to assess it (Slim \& Slimane, 2006; Sommer, 2012; Tang \& Gudergan, 2018). Despite the consolidation of globalisation, and the growing number of multinational companies, research in international businesses is still inconclusive regarding the measurement of international experience (Loncan \& Nique, 2010; Tang \& Gudergan, 2018). Different authors have opted for different ways to measure experience in international business, namely through the number of years the firm has been engaged in international activities (Batsakis \& Mohr, 2017; Batsakis \& Singh, 2019; Chung, Park, Lee, \& Kim, 2015; Love, Roper, \& Zhou, 2016; Tan \& Sousa, 2019), through the firm's network extension (Chetty, Eriksson, \& Lindbergh, 2006; Dow \& Larimo, 2009; Rabbiosi, Elia, \& Bertoni, 2012; Slangen \& Hennart, 2008; just to name a few) while others, such as Johanson \& Martín (2015), Putzhammer, Fainshmidt, Puck, \& Slangen, (2018) and Tang \& Gudergan (2018), even combined both to measure experience in international business. Other measures have also been proposed, such as indices or composite indicators (letto-Gillies, 1998; Sullivan, 1994; UNCTAD, 1995). The absence of a coherent approach to measure experience in previous research made it difficult to create a cumulative structure of theoretical concepts that provides purpose to subsequent studies (Sullivan, 1994). Notwithstanding, the existing measures allow us to understand the approaches taken in the study of international experience and the current state of the art, serving as a basis for future research in the area (Sommer, 2012).

This study aims to provide an overview of the different approaches and evaluate the advantages and disadvantages of each proposed indicator to measure the experience in international businesses. Having this in mind, the purpose of this work is to answer two research questions: what is the understanding of international businesses experience among academics? And what are the indicators used to assess international businesses? Furthermore, other terms for "international business experience" were considered to better understand the expressions that were used when studying this topic. Hence, to answer these research questions, this study is divided into five main sections. Firstly, the introduction reveals the context and the chosen approach. Then, the next section presents the research methodology. Thirdly, the literature review presents the study of the existing literature and reveals several perspectives regarding the existing measurements used to evaluate the experience in international businesses. The next section is the discussion, followed by the conclusion. An analysis of each measurement is done, as well as a general review of the theories found, the limitations of this work, recommendations for future research, and the managerial implications. 


\section{Methodology}

To effectively explore the issues related to the EU innovation policies and the sustainability of its energy sector a subset of literature has been selected to identify the best which is the motivation to innovate and what are the socio-economic benefits of innovation. Moreover, it is proposed to point out which are the existing impediments hampering the progress of the EU's energy market.

The methodology section should clarify the procedure that will be used in the systematic literature review. A systematic literature review allows the identification, evaluation of previous research so that new knowledge can be generated (Kitchenham, 2004; Torraco, 2005). The main steps to develop a literature review are the formulation of a research question, creation of a research plan, definition of inclusion and exclusion criteria, developing a research methodology and data collection, a literature review, assessment and discussion of results and future recommendations (Donato \& Donato, 2019). Inclusion and exclusion criteria are defined based on the research question (Sampaio \& Mancini, 2007).

According to Bradford's law, within each field of research, there are some journals that are the most prominent, as they contain most of the most relevant articles in the field (Bradford, 1934). Thus, in order to use Bradford's law, the search for scientific articles was restricted to a selected list of high impact journals in the area of international business presented by DuBois \& Reeb (2000). According to this law, approximately one-third of these journals contain more than $70 \%$ of the total number of selected articles (López-Duarte, González-Loureiro, Vidal-Suárez, \& González-Díaz, 2016). To select the articles a two-step process was followed. First, a keyword search was performed using the Scopus database with the keywords "international experience", "internationalisation" or "international business experience". In this research, we obtained 147 articles from the main journals in the area as mentioned above. Then, we filtered the articles that exactly mentioned the keywords in the title, abstract or keywords, and the final research was carried out within 66 articles.

Also, other relevant documents, such as reports, conference papers and articles from other journals were included, as their keywords matched the ones used in this study and they provided valuable information. 
Figure 1 - Selected papers that matched the keyword research

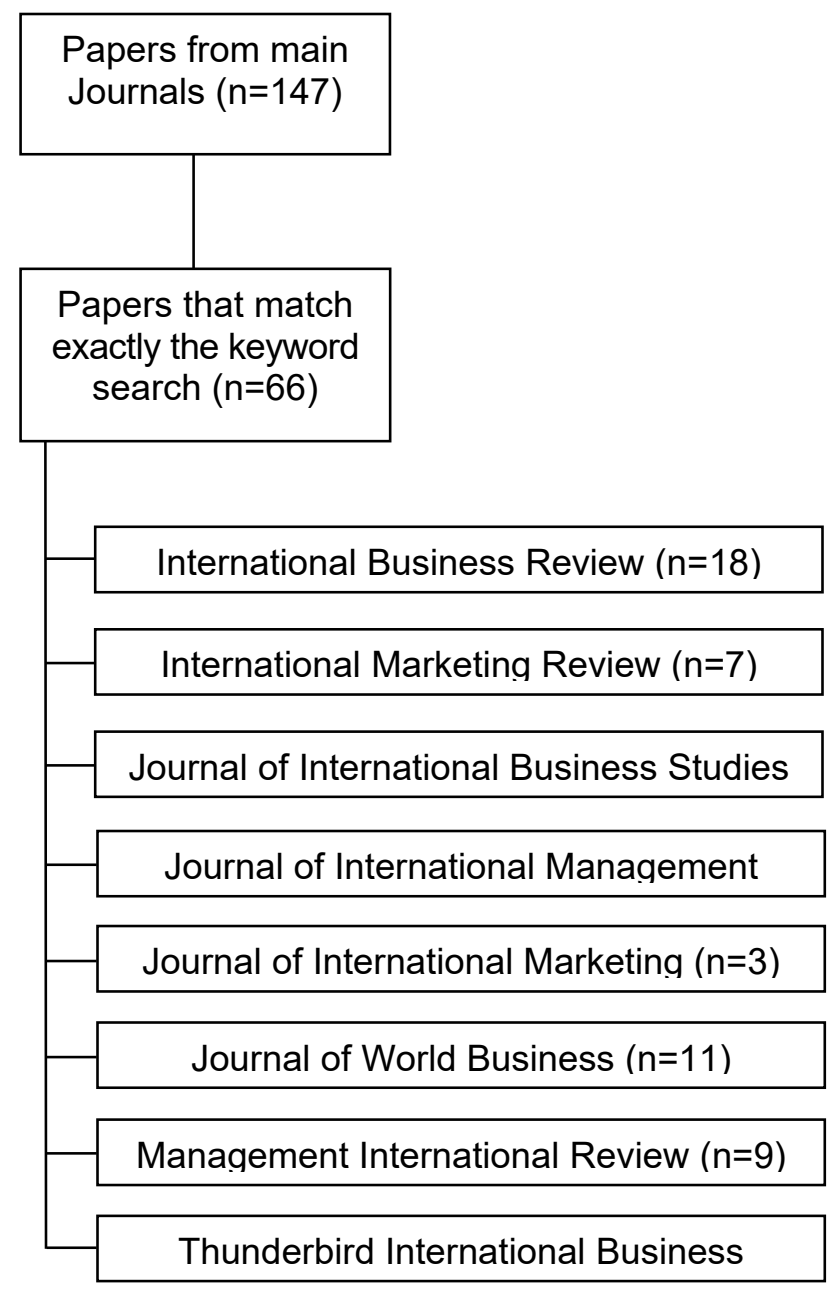

3. Literature Review

\subsection{Division of Themes}

International experience is a relevant variable that helps to alleviate some of the threats encountered during the internationalisation process (Barkema et al., 1996; Szymura-Tyc, 2013). Firms with higher levels of international business experience are better prepared to face possible adversities in the internationalisation process, cope with complex differences in the new market, and end up managing associated costs of doing business in an international environment more effectively (Batsakis \& Singh, 2019). However, several authors use this concept differently (Szymura-Tyc, 2013). Authors like Batsakis \& Mohr, 2017; Batsakis \& Singh, 2019; Chung et al., 2015; Love et al., 2016; Tan \& Sousa, 2019 measured international 
business experience through the number of years the firm has been involved in international activities. Moreover, other authors (among which Chetty, Eriksson, \& Lindbergh (2006), Dow \& Larimo (2009), Rabbiosi, Elia, \& Bertoni (2012) and Slangen \& Hennart (2008)) measured experience through the firm's network extension, while others, including Johanson \& Martín (2015), Putzhammer, Fainshmidt, Puck, \& Slangen, (2018) and Tang \& Gudergan (2018), combined both criteria to measure experience in international business. Other measures were also proposed, such as indices or composite indicators (letto-Gillies, 1998; Sullivan, 1994; UNCTAD, 1995). International business experience should be further investigated, as the lack of experience can make it difficult to overcome barriers imposed by the international market (Schiavini \& Scherer, 2015). In the view of Sommer (2012), international experience is an important source of information and it is used in a large number of studies, even though there is still much to be investigated about it. In particular, the author suggests that the conceptualisation and measurement of international experience are often done simplistically by using only secondary data available due to the lack of primary sources (Sommer, 2012).

In the table below shows the division made to organise the literature review: Number Of Years Of Foreign Operations \& Network Extension, Managers' International Experience, and Internationalisation Indices/Composites.

Table 1 - Division of Themes

\begin{tabular}{|c|c|}
\hline Theme & References \\
\hline $\begin{array}{l}\text { Number of Years of Foreign } \\
\text { Operations }\end{array}$ & $\begin{array}{l}\text { (Aguilera-Caracuel, Hurtado-Torres, \& Aragón-Correa, 2012; Ali, Lee, \& } \\
\text { Camp, 2003; Batsakis \& Mohr, 2017; Batsakis \& Singh, 2019; Child et } \\
\text { al., 2017; Chung et al., 2015; C. W. Hsu, Lien, \& Chen, 2015; P. Y. Li \& } \\
\text { Meyer, 2009; Love et al., 2016; Mutinelli \& Piscitello, 1997; } \\
\text { Papadopoulos \& Martín Martín, 2010; Prijcker, Manigart, Wright, \& } \\
\text { Maeseneire, 2012; Tan \& Sousa, 2019) }\end{array}$ \\
\hline $\begin{array}{l}\text { Network Extension (Number of } \\
\text { Foreign Countries where the } \\
\text { Company Exports/Operates) }\end{array}$ & $\begin{array}{l}\text { (Chetty et al., 2006; Dow \& Larimo, 2009, 2011; Rabbiosi et al., 2012; } \\
\text { Slangen \& Hennart, 2008) }\end{array}$ \\
\hline $\begin{array}{l}\text { Number of Years of Foreign } \\
\text { Operations \& Network } \\
\text { Extension }\end{array}$ & $\begin{array}{l}\text { (Arregle, Miller, Hitt, \& Beamish, 2018; Bai, Johanson, \& Martín Martín, } \\
\text { 2017; Evans, Mavondo, \& Bridson, 2008; Hohenthal, Johanson, \& } \\
\text { Johanson, 2014; M. Johanson \& Martín, 2015; Mohr \& Batsakis, 2014; } \\
\text { Mutinelli \& Piscitello, 2001; Putzhammer et al., 2018; Schwens, Zapkau, } \\
\text { Brouthers, \& Hollender, 2018; Tang \& Gudergan, 2018) }\end{array}$ \\
\hline $\begin{array}{l}\text { Managers' International } \\
\text { Experience }\end{array}$ & $\begin{array}{l}\text { (Bianchi, 2009; Boellis, Mariotti, Minichilli, \& Piscitello, 2016; Bouquet, } \\
\text { Morrison, \& Birkinshaw, 2009; Chandra, Styles, \& Wilkinson, 2009; Chen, } \\
\text { Chang, \& Hsu, 2017; Chen, Hsu, \& Chang, 2016; Chen, Zou, Xu, \& Chen, } \\
\text { 2020; Child \& Hsieh, 2014; Clark, Li, \& Shepherd, 2017; Cloninger, 2004; } \\
\text { Coeurderoy \& Murray, 2008; Cui, Li, Meyer, \& Li, 2015; García-García, } \\
\text { García-Canal, \& Guillén, 2017; Georgakakis, Dauth, \& Ruigrok, 2016; } \\
\text { González, 2019; Hollender, Zapkau, \& Schwens, 2017; Hsieh et al., } \\
\text { 2019; Hsu, Chen, \& Cheng, 2013; Huett, Baum, Schwens, \& Kabst, } \\
\text { 2014; Khan \& Lew, 2018; Le \& Kroll, 2017; Li, Qian, \& Qian, 2012; Li, } \\
\text { 2018; Magnusson \& Boggs, 2006; Maitland \& Sammartino, 2015; Nielsen \& } \\
\text { Nielsen, 2011; Nielsen, 2010; O’Donnell \& Jeong, 2000; Oura, Zilber, \& } \\
\text { Lopes, 2016; Oxelheim, Gregorič, Randøy, \& Thomsen, 2013; Ramsey, } \\
\text { Rutti, Lorenz, Barakat, \& Sant’anna, 2017; Sousa \& Tan, 2015; Yeoh, 2004) }\end{array}$ \\
\hline $\begin{array}{l}\text { International } \\
\text { Indices/Composites }\end{array}$ & $\begin{array}{l}\text { (Aybar \& Ficici, 2009; Bortoluzzi, Chiarvesio, Di Maria, \& Tabacco, 2014; } \\
\text { Chen et al., 2017; Dörrenbächer, 2000; Elango \& Pattnaik, 2007; Gaur, Ma, } \\
\text { \& Ding, 2018; letto-Gillies, 1998; Liao, 2015; Sullivan, 1994; UNCTAD, 1995) }\end{array}$ \\
\hline
\end{tabular}




\subsection{Number of Years of Foreign Operations \& Network Extension}

Structural indicators are intended to illustrate a company's international involvement in a given period (Curwen \& Whalley, 2006). Some examples of indicators that make up this way of measuring the internationalisation of a company are related to the activities carried out by the company at an international level, such as the total number of years the company has been operating abroad, number of markets in which a company is present, the number of foreign affiliates, the number of relationships established with other companies (e.g. strategic alliances), the proportion of foreign assets and goods supplied abroad, as well as the ratio of local labour to foreign labour (Dörrenbächer, 2000; Jankowska, 2011).

Several studies have used the number of years the company has been involved in foreign operations as a measurement of the firm's international experience (Aguilera-Caracuel et al., 2012; Ali et al., 2003; Arregle et al., 2018; Bai et al., 2017; Batsakis \& Mohr, 2017). This way of measuring the international experience of a firm is associated to the depth and intensity of a firm's experience abroad (Battaglia \& Neirotti, 2020; Cadogan, Diamantopoulos, \& Siguaw, 2002; Erramilli, 1991; Miller, Lavie, \& Delios, 2016). Another approach to measuring international experience is to focus on the network extension, that is, the number of countries in which the company is present.

Numerous authors (such as Chetty et al., 2006; Dow \& Larimo, 2009, 2011; Rabbiosi et al., 2012; Slangen \& Hennart, 2008) opted to measure the international business experience of the firm based on the extension of its network, i.e. through the number of foreign countries where the company operates. Similarly to what was described above concerning the number of years of international activity, here the number of regions where the firm operates measures the breadth and diversity of this experience (Battaglia \& Neirotti, 2020; Cadogan et al., 2002; Erramilli, 1991; Miller et al., 2016).

Some authors, for example Arregle et al. (2018), Bai et al. (2017), Erramilli (1991), Hohenthal et al. (2014), Johanson \& Martín (2015), Kogut \& Singh (1988), Schwens et al. (2018) and Silva et al., (2012) adopted the combination of the number of years the firm has been engaged in international activities and the number of regions where the firm operates in an attempt to better measure international experience. These measures of international experience are related to the psychic distance argument, in the way that less experienced companies favour entering foreign markets that are similar to the country of origin (Johanson \& Vahlne, 1977). Yet, as their experience abroad increases and becomes more diversified, these firms will increasingly seek other markets which are geographically and culturally distant (Erramilli, 1991).

\subsection{Managers' International Experience}

Although there are no consensual opinions, and doubts remain about whether attitudinal indicators can be measured with sufficient reliability, there are authors who encourage their use, as expressed by Perlmutter \& Heenan (1979). To the authors, the existence of external and quantifiable dimensions, such as the percentage of investment abroad, are useful, but they are not enough. The more it is known about the reality of the 
decision-making process, the more weight should be given to the aspects that influence executives' vision on international business (Perlmutter \& Heenan, 1979).

Sullivan (1994) proposed to measure international experience as the number of years that managers have lived abroad. The author argues that this can be better measured statistically, and companies will gain more international predisposition the more international experience of top managers. The measure can be calculated as the total years that managers spent working abroad, divided by the number of years they have of working experience. Based on Sullivan's proposal, some authors based their measurement of international experience on management teams' international experience (Bianchi, 2009; Chandra et al., 2009; Clark et al., 2017; Hollender et al., 2017; Li et al., 2012; Yeoh, 2004). According to Sommer (2012), the way management teams' international experience is measured in these studies can be divided into using a dummy variable in a complementary way (managers have international experience vs managers do not have international experience) (for example Chen et al., 2016; Coeurderoy \& Murray, 2008; Magnusson \& Boggs, 2006), or by the time spent living, working or studying abroad as the main way to measure experience (Chen et al., 2020; Le \& Kroll, 2017; Li, 2018; O’Donnell \& Jeong, 2000, just to name a few).

\subsection{Internationalisation Indices/Composites}

Indices or composite indicators are designed by linking two or more individual indicators. Although several studies use individual indicators, the consensus opinion is that composite indicators are more suitable for measuring internationalisation (Dörrenbächer, 2000). This is because individual indicators are not very reliable when isolated since it is not possible to control the measurement error associated with them, or the influences of the external environment and the manipulation of the transfer price (Dörrenbächer, 2000).

The United Nations Conference on Trade and Development proposed a composite index of transnationality - the Transnationality Index - that assesses the degree of involvement of companies in international activities compared to their total of activities (UNCTAD, 1995). This index aims to provide an overview of a company's position in the internationalisation process. The transnationality index is calculated through the average of three ratios:

- The shares of foreign sales in total sales;

- The foreign assets in total assets;

- And foreign employment in total employment.

Furthermore, the Transnational Activities Spread Index proposed by lettoGillies, based on the Network Spread Index and the Transnationality Index proposed by UNCTAD, focuses more on the spread of activities per countries in which the firm operates (letto-Gillies, 1998), and is therefore considered as an improved version of UNCTAD's Transnationality Index. The Transnational Activities Spread Index is calculated by doing the average of the ratios of foreign sales to total sales, foreign assets to total assets and foreign employment to total employment (the same ones as in the Transnationality Index), and then these are multiplied by the number of countries in which the company operates in proportion to the total of foreign countries in which it can operate (from the Network Spread Index) (letto-Gillies, 1998). 
Ultimately, Sullivan (1994) proposed an index that covers three different dimensions by combining structural (ratio of foreign assets to total assets and ratio of foreign affiliates to total affiliates), performance (ratio of foreign sales to total sales) and attitudinal indicators (international experience of top management and psychic dispersion of international operations), the Degree of Internationalisation (DOI). This index has been used by several authors that argue that international experience is better measured by combining structural or performance ratios (Aybar \& Ficici, 2009; Bortoluzzi et al., 2014; Chen et al., 2017; Elango \& Pattnaik, 2007; Gaur et al., 2018; Liao, 2015).

The main disadvantage of using the number of years and markets in which a company has been engaged in international activities to assess its international experience is that these are over-simplistic measures, which do not bring additional information. The key limitation of the indices analysed is that they are mainly focused on the internationalisation of TNCs. Secondly, the fact that primary data is difficult to obtain, makes most of the researchers base their study on secondary data only, which may have incomplete information or not be specific to the researcher's needs. Or, whenever primary data exists, it is usually fragmented, the availability of data varies a lot from country to country, and, in the case of accounting figures, existing different accounting rules make the research more difficult.

We were able to find that all of the studies use experience as a secondary variable, and some of them (for example Chen et al., 2016; Coeurderoy \& Murray, 2008; Magnusson \& Boggs, 2006) use it as a dummy variable which does not allow a comprehensive measurement of experience in international business (Slim \& Slimane, 2006; Sommer, 2012). At the end, it is possible to assess that there are methods that provide a more quantifiable measurement of experience in international business, as is the case of Silva et al. (2012) which adopts the number of years the firm has been engaged in international activities and the number of regions where the firm operates to better measure international experience of the firm. On another hand, after evaluating the different alternatives for measuring experience in international business, we can see that there are methods of measuring experience that do not provide sufficient information about the experience organisations have in doing businesses internationally. An example of this is the international experience of managers. By measuring top managers' international experience we are assessing experience as knowledge acquired in activities carried out abroad, whether through studies, work or personal life experiences. We cannot say that this knowledge is not relevant, however, when it comes to using this indicator as a measure of a company's experience in international business, it may provide misleading information as this experience is being measured taking into account one or several individuals in the top management team.

\section{Discussion}

The objective of this work is to provide an overview of the different approaches to assess international business and critically evaluate each one of them. Moreover, the purpose was also to answer two research questions: what is the understanding of international businesses experience among academics? And what are the indicators used to assess international businesses?

Even though globalisation is a contemporary matter, research in international business needs a better understanding of the concept of internationalisation 
experience (Loncan \& Nique, 2010; Tang \& Gudergan, 2018). The existing problem when we approach international businesses is related to the existence of several ways to measure experience (Dörrenbächer, 2000). As we have previously seen, experience has been measured differently in past studies: through the number of years involved in international activities, the network extension, both measurements combined, and as indices or composite indicators.

Structural indicators are intended to illustrate the company's international involvement in a given period of time (Curwen \& Whalley, 2006). As examples of this type of indicators, we have seen the number of markets in which the company operates abroad and the duration in years of the activities in which the company is involved internationally (Dörrenbächer, 2000). As seen aforementioned, some authors measure international experience by considering the number of years a company has been present abroad (Batsakis \& Mohr, 2017; Batsakis \& Singh, 2019; Chung et al., 2015; Love et al., 2016; Tan \& Sousa, 2019). This way of measuring the international experience of a firm is associated to the depth and intensity of a firm's experience abroad and provides a straightforward and simple way to measure either SMEs or TNCs experience in international business. Considering the Network Extension, this measure is done by focusing on the number of countries in which the company is present. This measure takes on the breadth and diversity of experience in international business (Battaglia \& Neirotti, 2020; Cadogan et al., 2002; Erramilli, 1991; Miller et al., 2016), and it is relevant given that many problems that could arise may be related to the geographical distribution of business activities. Having a network spread across different countries brings its advantages and disadvantages. On one hand, having activities spread through different countries can lower down the risk of having to rely on one market only and can bring new knowledge to the company. These can be translated into a higher competitive advantage. However, on the other hand, one limitation of this measure is that it fails to capture the importance of a particular country in the firm's operations. Countries are equally weighted, even if most international activities take place in a limited number of host markets. Furthermore, other authors combined both metrics and measured experience through the number of years a company has been present abroad and by the network spread (Arregle et al., 2018; Bai et al., 2017; Erramilli, 1991; Evans et al., 2008; Hohenthal et al., 2014; M. Johanson \& Martín, 2015; Kogut \& Singh, 1988; Mohr \& Batsakis, 2014; Mutinelli \& Piscitello, 2001; Putzhammer et al., 2018; Schwens et al., 2018; Silva et al., 2012; Tang \& Gudergan, 2018). By combining both measurements, the experience can be assessed regarding the depth and intensity, and breadth and diversity of a firm's experience abroad. Measuring experience through the number of years of foreign operations and network extension can also be related to the psychic distance between markets, as companies with less experience abroad are more likely to choose to enter a foreign market that is psychically closer to the home market. However, as they gain experience throughout the years, they will become more diversified and, consequently, seek other markets which are further distant (Erramilli, 1991). Although easy to use, when applied in isolation, these indicators provide an overly simplistic assessment of the involvement of companies and their international businesses, ignoring many other factors that are considered relevant for assessing the international experience of a firm (Szymura-Tyc, 2013). 
The internationalisation indices are designed by linking two or more individual indicators. In this study, we approached the UNCTAD's Transnationality Index, the Transnational Activities Spread Index (letto-Gillies, 1998) and the Degree of Internationalisation (Sullivan, 1994). Including several indicators to measure the internationalisation of firms provides more significant results than using a single indicator since individual indicators make it difficult to control the measurement error, or the influences of the external environment and the manipulation of the transfer price (Dörrenbächer, 2000; Slim \& Slimane, 2006). The Transnationality Index by the UNCTAD (1995) assesses the degree of involvement of companies in international activities compared to their total activities. This is calculated through the average of three ratios: shares of foreign sales in total sales, foreign assets in total assets and foreign employment in total employment. In this index, a company is considered to be internationalised if its foreign to total activities ratio is very high, regardless of whether those foreign activities happen in one or more country or region. Also, the interpretation of any results obtained through this index can only be applied to large companies, since their size and growth are linked to their activities abroad (letto-Gillies, 1998). Consequently, this index cannot be applied to small and medium-sized companies, which represent the "backbone" of the European economy (Eurostat, 2019). However, letto-Gillies's (1998) proposed an improved version of UNCTAD's Transnationality Index, the Transnational Activities Spread Index, which focuses more on the spread of activities per countries in which the firm operates. The Transnational Activities Spread Index is a combination of the average of the share of activities abroad, represented by the foreign sales to total sales, foreign assets to total assets and foreign employment to total employment (the same ratios used in the Transnationality Index); these are then multiplied by the number of countries in which the company operates in proportion to the total of foreign countries in which it can operate (letto-Gillies, 1998). This way, this index allows us to conclude that the degree of internationalisation of a company increases, the more activities the company has abroad and the greater the spread of these activities in foreign countries. Ultimately, Sullivan (1994) proposes the Degree of Internationalisation which covers three different dimensions, combining structural (ratio of foreign assets to total assets and ratio of foreign affiliates to total affiliates), performance (ratio of foreign sales to total sales) and attitudinal indicators (international experience of top management and psychic dispersion of international operations). Despite combining three types of indicators, there are doubts about the feasibility to measure experience using the attitudinal indicators included in the index (Dörrenbächer, 2000).

Although there are no consensual opinions and doubts remain about whether attitudinal indicators can be measured with sufficient reliability (Sullivan, 1994), there are authors who encourage their use, as expressed by Perlmutter \& Heenan (1979). Thus, more weight should be given to attitudinal indicators like the top managers' international experience, as this will influence their decision-making process. This way, Sullivan (1994) proposed an attitudinal indicator to measure international experience based on the number of years that managers have worked, lived and studied abroad divided by the number of years they have of working experience. Based on this proposal, some authors based their measurement of international experience on management teams' international experience (Bianchi, 2009; Chandra et al., 2009; Clark et al., 2017; Hollender et al., 2017; Li et al., 2012; 
Yeoh, 2004). As observed, the way managers' international experience is measured either by using a dummy variable (managers have international experience vs managers do not have international experience) (for example Chen et al., 2016; Coeurderoy \& Murray, 2008; Magnusson \& Boggs, 2006) or by the years spent living, working or studying abroad (Chen et al., 2020; Le \& Kroll, 2017; Li, 2018; O'Donnell \& Jeong, 2000, just to name a few). Companies that rely on exporting and international operations, place considerable emphasis on managerial qualities necessary to conduct business on an international scale (Ali et al., 2003). Involvement in international activities and working abroad make executives aware of the nature and complexity of international operations. Thus, the experience abroad, whether due to work or studies, strengthens the commitment and the international involvement of the manager and consequently of the company, which will be more easily involved in international operations. The international experience that executives acquire while studying or working abroad allows them to expand horizons and acquire new knowledge and rethink strategies to apply in their companies. Although it is an indirect way of measuring the international experience of companies, the international experience of managers can help companies to leverage and detect new opportunities in foreign markets.

\section{Conclusions}

Building on the frameworks reviewed (number of years of foreign operations, network extension, managers' international experience and international indices/composites), it is possible to conclude that these are not contradictory on their scope nor on their approach to studying experience in international business. On the contrary, these models are complementary in the way that through individual international indicators we can measure experience by counting the number of years abroad and the number of countries where the company operates and build indices, such as the Transnationality Index and the Transnational Activities Spread Index. Nevertheless, of the models studied, the one that allows us to measure more clearly the experience in international business is the combination of the factors of: the number of years of foreign operations and network extension since through the years of experience and presence in different markets, managers and companies are learning and retaining knowledge regarding the decisions they make. Thus, this combination allows the experience in international business to be accurately measured through what has been learnt from entering each market over the years. This represents an easy way to estimate a metric measure because it requires the company's network extension, as well as the total number of years in which it is involved in international business.

Regarding managerial implications, this work provides a study of several indicators that allow the measurement of internationalisation of companies. This work provides an overview of the company's current situation and compares it with its competitors. In this sense, experience allows companies to acquire knowledge which allows them to anticipate possible problems in the international context (Cieślik, Kaciak, \& van Stel, 2018), as well as to explore new opportunities and cope with threats in the foreign market (Zou \& Stan, 1998). As from a dynamic capabilities view, a firm needs to perceive international opportunities in foreign 
markets, seize country-specific strategic decisions, and allocate intangible and tangible assets for developing or maintaining the firm's competitive position in the market (Tang \& Gudergan, 2018), to which international experience will contribute, by allowing firms to better cope with the challenges imposed.

As future research directions a deeper analysis is needed to establish the utility of the frameworks in the assessment of the effects of international experience on company activities abroad (letto-Gillies, 1998). Additionally, the adaptation and employment of internationalisation indices in the case of SMEs should also be studied. Lastly, the conceptualisation and the measurement of international experience are often done commonly by using secondary data available due to the lack of primary data sources (Sommer, 2012). More robust studies should be done based on primary data sources, with representative samples and better statistical models, such as panel data or time series analysis (Loncan \& Nique, 2010). Having said that, some of the questions that would be interesting to see studied in future work on the subject would be: to what extent does the international experience of managers have an impact on the international expansion of companies (i.e. on FDI)? Can the indices mentioned in this work be adapted and applied to measure the international business experience of SMEs? And how do CEOs measure and compare the international experience of their companies?

\section{References}

Aguilera-Caracuel, J., Hurtado-Torres, N. E., \& Aragón-Correa, J. A. (2012). Does international experience help firms to be green? A knowledge-based view of how international experience and organisational learning influence proactive environmental strategies. International Business Review, 21(5), 847-861. https://doi.org/10.1016/j.ibusrev.2011.09.009

Ali, A. J., Lee, M., \& Camp, R. C. (2003). Export Attitudes of Taiwanese Executives. Journal of Global Marketing, 16(1-2), 27-46. https://doi.org/10.1300/J042v16n01_02

Arregle, J. L., Miller, T. L., Hitt, M. A., \& Beamish, P. W. (2018). The role of MNEs' internationalization patterns in their regional integration of FDI locations. Journal of World Business, 53(6), 896-910. https://doi.org/10.1016/j.jwb.2018.07.004

Aybar, B., \& Ficici, A. (2009). Cross-border acquisitions and firm value: An analysis of emerging-market multinationals. Journal of International Business Studies, 40(8), 1317-1338. https://doi.org/10.1057/jibs.2009.15

Bai, W., Johanson, M., \& Martín Martín, O. (2017). Knowledge and internationalization of returnee entrepreneurial firms. International Business Review, 26(4), 652-665. https://doi.org/10.1016/j.ibusrev.2016.12.006

Barkema, H. G., Bell, J., \& Pennings, J. M. (1996). Foreign entry, cultural barriers, and learning. Strategic Management Journal. https://doi.org/10.1002/(sici)10970266(199602)17:2<151::aid-smj799>3.3.co;2-q

Batsakis, G., \& Mohr, A. T. (2017). Revisiting the relationship between product diversification and internationalization process in the context of emerging market MNEs. Journal of World Business, 52(4), 564-577. https://doi.org/10.1016/j.jwb.2016.11.005 
Batsakis, G., \& Singh, S. (2019). Added distance, entry mode choice, and the moderating effect of experience: The case of British MNEs in emerging markets. Thunderbird International Business Review, 61(4), 581-594. https://doi.org/10.1002/tie.22046

Battaglia, D., \& Neirotti, P. (2020). Dealing with the tensions between innovation and internationalization in SMEs: A dynamic capability view. Journal of Small Business Management, 26.

Bianchi, C. (2009). Retail internationalisation from emerging markets: Case study evidence from Chile. International Marketing Review, 26(2), 221-243. https://doi.org/10.1108/02651330910950439

Boellis, A., Mariotti, S., Minichilli, A., \& Piscitello, L. (2016). Family involvement and firms' establishment mode choice in foreign markets. Journal of International Business Studies, 47(8), 929-950. https://doi.org/10.1057/jibs.2016.23

Bortoluzzi, G., Chiarvesio, M., Di Maria, E., \& Tabacco, R. (2014). Exporters moving toward emerging markets: A resource-based approach. International Marketing Review, 31(5), 506-525. https://doi.org/10.1108/IMR-12-2013-0280

Bouquet, C., Morrison, A., \& Birkinshaw, J. (2009). International attention and multinational enterprise performance. Journal of International Business Studies, 40(1), 108-131. https://doi.org/10.1057/jibs.2008.64

Bradford, S. C. (1934). Sources of information on specific subjects. Engineering, 137, 85-86.

Cadogan, J. W., Diamantopoulos, A., \& Siguaw, J. A. (2002). Export market-oriented activities: Their antecedents and performance consequences. Journal of International Business Studies.

Chandra, Y., Styles, C., \& Wilkinson, I. (2009). The recognition of first time international entrepreneurial opportunities: Evidence from firms in knowledgebased industries. International Marketing Review, 26(1), 30-61. https://doi.org/10.1108/02651330910933195

Chen, H. L., Chang, C. Y., \& Hsu, W. T. (2017). Does Board Co-Working Experience Influence Directors' Decisions Toward Internationalization? Management International Review, 57(1), 65-92. https://doi.org/10.1007/s11575-016-0309-4

Chen, H. L., Hsu, W. T., \& Chang, C. Y. (2016). Independent directors' human and social capital, firm internationalization and performance implications: An integrated agency-resource dependence view. International Business Review, 25(4), 859-871. https://doi.org/10.1016/j.ibusrev.2015.10.010

Chen, L., Zou, S., Xu, H., \& Chen, Y. (2020). Entrepreneurial Orientation in Multinational Corporations: Antecedents and Effects. Management International Review, 60(1), 123-148. https://doi.org/10.1007/s11575-019-00397-4

Chetty, S., Eriksson, K., \& Lindbergh, J. (2006). The effect of specificity of experience on a firm's perceived importance of institutional knowledge in an ongoing business. Journal of International Business Studies, 37(5), 699-712. https://doi.org/10.1057/palgrave.jibs.8400214

Child, J., Hsieh, L., Elbanna, S., Karmowska, J., Marinova, S., Puthusserry, P., Zhang, Y. (2017). SME international business models: The role of context and experience. Journal of World Business, 52(5), 664-679. https://doi.org/10.1016/j.jwb.2017.05.004

Child, J., \& Hsieh, L. H. Y. (2014). Decision mode, information and network attachment in the internationalization of SMEs: A configurational and contingency analysis. Journal of World Business, 49(4), 598-610. https://doi.org/10.1016/j.jwb.2013.12.012 
Chung, C. C., Park, H. Y., Lee, J. Y., \& Kim, K. (2015). Human capital in multinational enterprises: Does strategic alignment matter". Journal of International Business Studies, 46(7), 806-829. https://doi.org/10.1057/jibs.2015.15

Cieślik, J., Kaciak, E., \& van Stel, A. (2018). Country-level determinants and consequences of overconfidence in the ambitious entrepreneurship segment. International Small Business Journal: Researching Entrepreneurship, 36(5), 473-499.

Clark, D. R., Li, D., \& Shepherd, D. A. (2017). Country familiarity in the initial stage of foreign market selection. Journal of International Business Studies, 49(4), 442-472. https://doi.org/10.1057/s41267-017-0099-3

Cloninger, P. A. (2004). The effect of service intangibility on revenue from foreign markets. Journal of International Management, 10(1 SPEC ISS.), 125-146. https://doi.org/10.1016/j.intman.2003.12.007

Coeurderoy, R., \& Murray, G. (2008). Regulatory environments and the location decision: Evidence from the early foreign market entries of new-technologybased firms. Journal of International Business Studies, 39(4), 670-687. https://doi.org/10.1057/palgrave.jibs.8400369

Cui, L., Li, Y., Meyer, K. E., \& Li, Z. (2015). Leadership Experience Meets Ownership Structure: Returnee Managers and Internationalization of Emerging Economy Firms. Management International Review, 55(3), 355387. https://doi.org/10.1007/s11575-014-0221-8

Curwen, P., \& Whalley, J. (2006). Measuring internationalisation in the mobile telecommunications industry. International Business Review, 15(6), 660-681.

Donato, H., \& Donato, M. (2019). Etapas na Condução de uma Revisão Sistemática. Acta Médica Portuguesa, 32(3), 227-235.

Dörrenbächer, C. (2000). Measuring corporate internationalisation - A review of measurement concepts and their use. Intereconomics, 35(3), 119-126.

Dow, D., \& Larimo, J. (2009). Challenging the Conceptualization and Measurement of Distance and International Experience in Entry Mode Choice Research. Journal of International Marketing, 17(2), 74-98. https://doi.org/10.1509/jimk.17.2.74

Dow, D., \& Larimo, J. (2011). Disentangling the Roles of International Experience and Distance in Establishment Mode Choice. Management International Review, 51(3), 321-355. https://doi.org/10.1007/s11575-011-0080-5

DuBois, F. L., \& Reeb, D. (2000). Ranking the international business journals. Journal of International Business Studies, 31(4), 689-704.

Elango, B., \& Pattnaik, C. (2007). Building capabilities for international operations through networks: A study of Indian firms. Journal of International Business Studies, 38(4), 541-555. https://doi.org/10.1057/palgrave.jibs.8400280

Erramilli, M. K. (1991). The Experience Factor in Foreign Market Entry Behavior of Service Firms. Journal of International Business Studies.

Eurostat. (2019). Key Figures on Europe. Luxembourg.

Evans, J., Mavondo, F. T., \& Bridson, K. (2008). Psychic distance: Antecedents, retail strategy implications, and performance outcomes. Journal of International Marketing, 16(2), 32-63. https://doi.org/10.1509/jimk.16.2.32

García-García, R., García-Canal, E., \& Guillén, M. F. (2017). Rapid internationalization and long-term performance: The knowledge link. Journal of World Business, 52(1), 97-110. https://doi.org/10.1016/j.jwb.2016.09.005 
Gaur, A. S., Ma, X., \& Ding, Z. (2018). Home country supportiveness/unfavorableness and outward foreign direct investment from China. Journal of International Business Studies, 49(3), 324-345. https://doi.org/10.1057/s41267-017-0136-2

Georgakakis, D., Dauth, T., \& Ruigrok, W. (2016). Too much of a good thing: Does international experience variety accelerate or delay executives' career advancement? Journal of World Business, 51(3), 425-437. https://doi.org/10.1016/j.jwb.2015.11.008

González, C. (2019). Revealing a Social Dimension of Internationalization: Transnational Board Interlocks as a Social-Based Proxy for the Degree of Internationalization of the Firm. Management International Review, 59(2), 253-276. https://doi.org/10.1007/s11575-018-0359-x

Heenan, D. A., \& Perlmutter, H. V. (1979). Multinational Organization Development: A Social Architectural Perspective. Administrative Science Quarterly.

Hohenthal, J., Johanson, J., \& Johanson, M. (2014). Network knowledge and business-relationship value in the foreign market. International Business Review, 23(1), 4-19. https://doi.org/10.1016/j.ibusrev.2013.08.002

Hollender, L., Zapkau, F. B., \& Schwens, C. (2017). SME foreign market entry mode choice and foreign venture performance: The moderating effect of international experience and product adaptation. International Business Review, 26(2), 250-263. https://doi.org/10.1016/j.ibusrev.2016.07.003

Hsieh, L., Child, J., Narooz, R., Elbanna, S., Karmowska, J., Marinova, S., Zhang, Y. (2019). A multidimensional perspective of SME internationalization speed: The influence of entrepreneurial characteristics. International Business Review, 28(2), 268-283. https://doi.org/10.1016/j.ibusrev.2018.09.004

Hsu, C. W., Lien, Y. C., \& Chen, H. (2015). R\&D internationalization and innovation performance. International Business Review, 24(2), 187-195. https://doi.org/10.1016/j.ibusrev.2014.07.007

Hsu, W. T., Chen, H. L., \& Cheng, C. Y. (2013). Internationalization and firm performance of SMEs: The moderating effects of CEO attributes. Journal of World Business, 48(1), 1-12. https://doi.org/10.1016/j.jwb.2012.06.001

Huett, P., Baum, M., Schwens, C., \& Kabst, R. (2014). Foreign direct investment location choice of small- and medium-sized enterprises: The risk of value erosion of firm-specific resources. International Business Review, 23(5), 952965. https://doi.org/10.1016/j.ibusrev.2014.02.007

letto-Gillies, G. (1998). Different conceptual frameworks for the assessment of the degree of internationalization: an empirical analysis of various indices for the top 100 transnational corporations. Transnational Corporations, 7(1), 17-39.

Jankowska, J. (2011). Measures of Company Internationalization. Financial Aspects of Organizational Management, 3.

Johanson, J., \& Vahlne, J.-E. (1977). The Internationalization Process of the Firm-A Model of Knowledge Development and Increasing Foreign Market Commitments. Journal of International Business Studies.

Johanson, M., \& Martín, O. (2015). The incremental expansion of Born Internationals: A comparison of new and old Born Internationals. International Business Review, 24(3), 476-496. https://doi.org/10.1016/j.ibusrev.2014.10.006 
Khan, Z., \& Lew, Y. K. (2018). Post-entry survival of developing economy international new ventures: A dynamic capability perspective. International Business Review, 27(1), 149-160. https://doi.org/10.1016/j.ibusrev.2017.06.001

Kitchenham, B. (2004). Procedures for performing systematic reviews. Keele University, Department of Computer Science.

Kogut, B., \& Singh, H. (1988). The Effect of National Culture on the Choice of Entry Mode. Journal of International Business Studies.

Le, S., \& Kroll, M. (2017). CEO international experience: Effects on strategic change and firm performance. Journal of International Business Studies, 48(5), 573-595. https://doi.org/10.1057/s41267-017-0080-1

Li, L., Qian, G., \& Qian, Z. (2012). Early internationalization and performance of small high-tech "born-globals." International Marketing Review, 29(5), 536561. https://doi.org/10.1108/02651331211260377

$\mathrm{Li}, \mathrm{P}$. Y. (2018). Top management team characteristics and firm internationalization: The moderating role of the size of middle managers. International Business Review, 27(1), 125-138. https://doi.org/10.1016/j.ibusrev.2017.05.011

Li, P. Y., \& Meyer, K. E. (2009). Contextualizing experience effects in international business: A study of ownership strategies. Journal of World Business, 44(4), 370-382. https://doi.org/10.1016/j.jwb.2008.11.007

Liao, T. J. (2015). Local clusters of SOEs, POEs, and FIEs, international experience, and the performance of foreign firms operating in emerging economies. International Business Review, 24(1), 66-76. https://doi.org/10.1016/j.ibusrev.2014.06.002

Loncan, T., \& Nique, W. (2010). Degree of Internationalization and performance: Evidence from emerging Brazilian multinational firms. Journal of Globalization, Competitiveness \& Governability.

López-Duarte, C., González-Loureiro, M., Vidal-Suárez, M. M., \& González-Díaz, B. (2016). International strategic alliances and national culture: Mapping the field and developing a research agenda. Journal of World Business, 51(4), 511-524.

Love, J. H., Roper, S., \& Zhou, Y. (2016). Experience, age and exporting performance in UK SMEs. International Business Review, 25(4), 806-819. https://doi.org/10.1016/j.ibusrev.2015.10.001

Magnusson, P., \& Boggs, D. J. (2006). International experience and CEO selection: An empirical study. Journal of International Management, 12(1), 107-125. https://doi.org/10.1016/j.intman.2006.01.002

Maitland, E., \& Sammartino, A. (2015). Managerial cognition and internationalization. Journal of International Business Studies, 46(7), 733-760. https://doi.org/10.1057/jibs.2015.9

Miller, S. R., Lavie, D., \& Delios, A. (2016). International intensity, diversity, and distance: Unpacking the internationalization-performance relationship. International Business Review.

Mohr, A., \& Batsakis, G. (2014). Intangible assets, international experience and the internationalisation speed of retailers. International Marketing Review, 31(6), 601-620. https://doi.org/10.1108/IMR-09-2013-0186

Mutinelli, M., \& Piscitello, L. (1997). Differences in the strategic orientation of Italian MNEs in Central and Eastern Europe. The influence of firm-specific factors. International Business Review, 6(2), 185-205. https://doi.org/10.1016/S09695931(96)00045-5 
Mutinelli, M., \& Piscitello, L. (2001). Foreign direct investment in the banking sector: The case of Italian banks in the '90s. International Business Review, 10(6), 661-685. https://doi.org/10.1016/S0969-5931(01)00037-3

Nielsen, B. B., \& Nielsen, S. (2011). The role of top management team international orientation in international strategic decision-making: The choice of foreign entry mode. Journal of World Business, 46(2), 185-193. https://doi.org/10.1016/j.jwb.2010.05.003

Nielsen, S. (2010). Top management team internationalization and firm performance. Management International Review, 50(2), 185-206. https://doi.org/10.1007/s11575-010-0029-0

O'Donnell, S., \& Jeong, I. (2000). Marketing standardization within global industries: An empirical study of performance implications. International Marketing Review, 17(1), 19-33. https://doi.org/10.1108/02651330010314696

Oura, M. M., Zilber, S. N., \& Lopes, E. L. (2016). Innovation capacity, international experience and export performance of SMEs in Brazil. International Business Review, 25(4), 921-932. https://doi.org/10.1016/j.ibusrev.2015.12.002

Oxelheim, L., Gregorič, A., Randøy, T., \& Thomsen, S. (2013). On the internationalization of corporate boards: The case of Nordic firms. Journal of International Business Studies, 44(3), 173-194. https://doi.org/10.1057/jibs.2013.3

Papadopoulos, N., \& Martín Martín, O. (2010). Toward a model of the relationship between internationalization and export performance. International Business Review, 19(4), 388-406. https://doi.org/10.1016/j.ibusrev.2010.02.003

Prijcker, S., Manigart, S., Wright, M., \& Maeseneire, W. (2012). The influence of experiential, inherited and external knowledge on the internationalization of venture capital firms. International Business Review, 21(5), 929-940. https://doi.org/10.1016/j.ibusrev.2011.11.001

Putzhammer, M., Fainshmidt, S., Puck, J., \& Slangen, A. (2018). To elevate or to duplicate? Experiential learning, host-country institutions, and MNE post-entry commitment increase. Journal of World Business, 53(4), 568-580. https://doi.org/10.1016/j.jwb.2018.03.004

Rabbiosi, L., Elia, S., \& Bertoni, F. (2012). Acquisitions by EMNCs in Developed Markets: An Organisational Learning Perspective. Management International Review, 52(2), 193-212. https://doi.org/10.1007/s11575-012-0134-3

Ramsey, J. R., Rutti, R. M., Lorenz, M. P., Barakat, L. L., \& Sant'anna, A. S. (2017). Developing global transformational leaders. Journal of World Business, 52(4), 461-473. https://doi.org/10.1016/j.jwb.2016.06.002

Sampaio, R., \& Mancini, M. (2007). Estudos De Revisão Sistemática: Um Guia Para Síntese Criteriosa Da Evidência Científica. Revista Brasileira de Fisioterapia.

Schiavini, J. M., \& Scherer, F. L. (2015). Review of International Business Overcoming liability of outsidership in China: The experience of Brazilian companies in developing Guanxi. Review of International Business, 10(3), 44-57.

Schwens, C., Zapkau, F. B., Brouthers, K. D., \& Hollender, L. (2018). Limits to international entry mode learning in SMEs. Journal of International Business Studies, 49(7), 809-831. https://doi.org/10.1057/s41267-018-0161-9

Silva, S. C., Bradley, F., \& Sousa, C. M. P. (2012). Empirical test of the trustperformance link in an international alliances context. International Business Review, 21(2), 293-306. 
Slangen, A. H. L., \& Hennart, J. F. (2008). Do multinationals really prefer to enter culturally distant countries through greenfields rather than through acquisitions? the role of parent experience and subsidiary autonomy. Journal of International Business Studies, 39(3), 472-490. https://doi.org/10.1057/palgrave.jibs.8400356

Slim, A., \& Slimane, A. S. (2006). Evaluate SMEs Internationalization. International Journal of Business \& Economic Strategy, 2.

Sommer, L. (2012). The Measurement of International Experience as a Dimension of Board Indices: Concept for an Improvement. International Journal of Business Administration, 3(4), 2-19.

Sousa, C. M. P., \& Tan, Q. (2015). Exit from a foreign market: Do poor performance, strategic fit, cultural distance, and international experience matter? Journal of International Marketing, 23(4), 84-104. https://doi.org/10.1509/jim.15.0003

Sullivan, D. (1994). Measuring the Degree of Internationalization of a Firm. Journal of International Business Studies, 25(2), 325-342.

Szymura-Tyc, M. (2013). Measuring the Degree of Firms' Internationalization at Their Early Stages of International Commitment. Journal of Economics \& Management.

Tan, Q., \& Sousa, C. M. P. (2019). Why Poor Performance is Not Enough for a Foreign Exit: The Importance of Innovation Capability and International Experience. Management International Review (Vol. 59). Springer Berlin Heidelberg. https://doi.org/10.1007/s11575-019-00384-9

Tang, R. W., \& Gudergan, S. P. (2018). A Meta-analysis of the International Experience-Ownership Strategy Relationship: A Dynamic Capabilities View. Management International Review, 58(4), 541-570. https://doi.org/10.1007/s11575-018-0349-z

Torraco, R. J. (2005). Writing Integrative Literature Reviews: Guidelines and Examples. Human Resource Development Review, 4(3), 356-367. https://doi.org/10.1177/1534484305278283

UNCTAD. (1995). World Investment Report 1995 Transnational Corporations and Competitiveness. United Nations Publication. New York.

Yeoh, P. L. (2004). International learning: Antecedents and performance implications among newly internationalizing companies in an exporting context. International Marketing Review, 21(4-5), 511-535. https://doi.org/10.1108/02651330410547171

Zou, S., \& Stan, S. (1998). The determinants of export performance: A review of the empirical literature between 1987 and 1997. International Marketing Review. 14(5), 333-356. https://doi.org/10.1108/02651339810236290 